\title{
ON THE STRUCTURE AND FORMATION OF EARTHQUAKE SOURCES IN THE FAULTS LOCATED IN THE SUBSURFACE AND DEEP LEVELS OF THE CRUST. PART I. SUBSURFACE LEVEL
}

\author{
V. V. Ruzhich' ${ }^{1}$, G. G. Kocharyan² \\ ${ }^{1}$ Institute of the Earth's crust, Siberian Branch of RAS, Irkutsk, Russia \\ ${ }^{2}$ Institute of Geosphere Dynamics of RAS, Moscow, Russia
}

\begin{abstract}
This study aims to analyze the internal structure of earthquake sources under the modern concepts in physical mesomechanics, which consider the multilevel process of faulting in the geological medium, taking into account specific features of the subsurface and deep levels of the crust. This article includes two parts that present the study results and discuss the interdisciplinary information on the subject of this study. The first part describes the subsurface crustal level, wherein seismogenic faulting takes place. We present the seismogeological data on the structure and development of the sources of three catastrophic earthquakes $(M \geq 8.0-8.5)$ that occurred in Mongolia in the last century. We discuss the deep drilling (1.0-3.5 km) data on the seismodislocations formed after the recent strong and catastrophic earthquakes in the United States, Taiwan and Japan, including the zone of co-seismic fractures caused by the Tohoku-Oki earthquake $(M=9.0$, November 11, 2011). In the second part, jointly with specialists in petrology and geochemistry A.V. Travin and V.B. Savelieva, we will analyze the field data on the ages and the physical and chemical characteristics of geomechanical processes that took place at large depths in the fault zones, which are outcropped by the long-term denudation of the upper crustal layer in the study area. In the summary, we will describe our concepts of geomechanical and tribochemical processes taking place in the fault zones during the formation of the earthquake sources. The results of this comprehensive study give grounds to conclude that a multidisciplinary approach is needed to investigate the deep geological and geophysical processes of 'stick-slip' on the fault planes with diverse relief features in the zones wherein seismicity is generated. This conclusion is of paramount importance: it concerns the potentials of applying new approaches to forecasting, management and mitigation of seismic engineering risks arising from the hazardous effects of strong earthquakes.
\end{abstract}

Key words: fault zone; earthquake source; seismodislocation; dislocation parameters; stick-slip; seismic safety

\section{RESEARCH ARTICLE}

Received: March 22, 2017

Recommended by K.Zh. Seminsky

For citation: Ruzhich V.V., Kocharyan G.G., 2017. On the structure and formation of earthquake sources in the faults located in the subsurface and deep levels of the crust. Part I. Subsurface level. Geodynamics \& Tectonophysics 8 (4), 1021-1034. doi:10.5800/GT-2017-8-4-0330.

Для цитирования: Ружич В.В., Кочарян Г.Г. О строении и формировании очагов землетрясений в разломах на приповерхностном и глубинном уровне земной коры. Статья І. Приповерхностный уровень // Геодинамика и тектонофизика. 2017. Т. 8. № 4. С. 1021-1034. doi:10.5800/GT-2017-8-4-0330. 


\title{
О СТРОЕНИИ И ФОРМИРОВАНИИ ОЧАГОВ ЗЕМЛЕТРЯСЕНИЙ В РАЗЛОМАХ НА ПРИПОВЕРХНОСТНОМ И ГЛУБИННОМ УРОВНЕ ЗЕМНОЙ КОРЫ. СТАТЬЯ І. ПРИПОВЕРХНОСТНЫЙ УРОВЕНЬ
}

\author{
В. В. Ружич ${ }^{1}$, Г. Г. Кочарян ${ }^{2}$ \\ ${ }^{1}$ Институт земной коры СО РАН, Иркутск, Россия \\ ${ }^{2}$ Институт динамики геосфер РАН, Москва, Россия
}

\begin{abstract}
Аннотация: Целью проведенного исследования был анализ внутреннего строения очагов землетрясений с точки зрения современных представлений в физической мезомеханике о многоуровневом процессе разломообразования в геологической среде, который обладает специфическими особенностями в приповерхностных и глубинных условиях земной коры. Результаты работы вследствие необходимости приведения значительного объема междисциплинарных сведений о предмете исследования публикуются в двух тесно взаимосвязанных статьях. Первая из них посвящена приповерхностному уровню сейсмогенного разрывообразования. Вначале представлены сейсмогеологические сведения о строении и развитии очагов трех катастрофических землетрясений (M $\geq 8.0-8.5)$, произошедших в прошлом столетии на территории Монголии. Затем анализируются материалы глубокого (1.0-3.5 км) бурения сейсмодислокаций, образовавшихся после недавних сильных и катастрофических землетрясений в США, на Тайване и в Японии, включая зону косейсмических разрывов суперземлетрясения Тохоку-Оки (11.11.2011 г. с М=9.0). Во второй статье планируется (с привлечением специалистов по изотопному датированию, петрологии и геохимии А.В. Травина и В.Б. Савельевой) проанализировать собранные при полевых работах сведения о возрасте и физико-химических характеристиках глубинных геомеханических процессов, происходивших ранее в зонах разломов, которые после длительного денудационного среза верхнего горизонта земной коры оказались эксгумированными. В заключение излагаются авторские представления о геомеханических и трибохимических процессах, происходивших в зонах разломов при формировании очагов землетрясений. Итогом комплексного исследования является вывод о необходимости мультидисциплинарного подхода к изучению глубинных геолого-геофизических процессов прерывистого контактного скольжения в плоскостях разломов с разнообразным рельефом неровностей в зонах сейсмогенерации. Данный вывод представляется первостепенно важным, поскольку он касается практической реализации возможностей создания новых подходов для прогнозирования, управления и смягчения инженерно-сейсмических рисков, возникающих при разрушительных последствиях сильных землетрясений.
\end{abstract}

Ключевые слова: разломная зона; очаг землетрясения; сейсмодислокация; параметры дислокаций; режим прерывистого скольжения; сейсмобезопасность

\section{1. ВВЕДЕНИЕ}

Наблюдаемые на нашей планете губительные последствия внезапных разрушительных землетрясений можно расценивать как свидетельство кризисного состояния в области решения проблем обеспечения сейсмобезопасности разнообразных коммуникаций и населения мегаполисов и небольших городов [Panza et al., 2014]. Одной из важнейших причин этого кризиса является дефицит сведений о процессах деструкции в земной коре, в частности, о механизмах и моделях подготовки очагов землетрясений в ее недрах. Существующие упрощенные модели очагов землетрясений, созданные в середине прошлого столетия преимущественно на основании интерпретации лабораторных экспериментов, уже не соответствуют совре- менным требованиям, необходимым для разработки более эффективных способов борьбы с последствиями природных и техногенных сейсмических катастроф. Основной причиной этого является отсутствие возможностей экспериментально воспроизводить глубинные трибофизические процессы динамометаморфического преобразования различных горных пород в разломах в присутствии сложных по составу флюидов и при повышенных давлениях и температурах с учетом геологических масштабов и продолжительности трибофизических изменений в разломах.

Цель комплексного исследования, результаты которого излагаются в двух статьях (I и II), - выявление и оценка значимости наиболее важных геолого-геофизических факторов, которые способствуют длительной подготовке и зарождению оча- 
гов сильных землетрясений в пределах сейсмофокального горизонта земной коры.

В статье I приведены собранные при участии авторов сведения о строении, масштабах, длительности и сценариях возникновения систем сейсмодислокаций на земной поверхности в моменты проявления при недавних катастрофических землетрясениях в пределах территории Монголии. Кроме того, большое внимание уделено новым результатам бурения, проведенного в зонах некоторых подобных сейсмических событий. Полученная при этом специалистами разных стран уникальная информация рассматривается в плане возможности расширения представлений о строении и геомеханических процессах во внутренних участках зон сейсмогенерирующих разломов, проявившихся на приповерхностных глубинах земной коры 1.0-3.5 км.

В статье II планируется обсудить возможность восполнения имеющегося недостатка знаний путем сбора новой геолого-геофизической информации при изучении геологического строения сейсмодислокаций на более удаленных от поверхности глубинных уровнях с применением физикохимического метода и анализа выявленных признаков стресс-метаморфического преобразования различных по составу горных пород в моменты косейсмических смещений в очагах палеоземлетрясений. В качестве объектов были выбраны сегменты глубоко денудированной зоны раннепалеозойского коллизионного шва в Центральном Прибайкалье, где располагается и зона Приморского рифтогенного сброса кайнозойского возраста заложения. Сброс рассматривается как фрагмент сейсмотектонической активизации участка коллизионного шва при возникновении Байкальского рифта, начавшегося приблизительно 70 млн лет назад. В отмеченных местах были обнаружены многочисленные разномасштабные и разновозрастные косейсмические разрывы, выявленные по ряду признаков, в частности по зеркалам скольжения. Обсуждаются сведения о возрасте этапов активизации Приморского разлома в пределах коллизионного шва, а также оценка изотопного датирования актов возникновения зеркал скольжения в косейсмических разрывах, в том числе с выявленной турмалиновой минерализацией.

В заключительной части данной работы будет представлено обоснование основного по важности вывода о возможности предметной оценки условий и причин зарождения очагов сильных землетрясений на уровне залегания сейсмофокального горизонта в земной коре Центральной Азии. Планируется показать, что именно на этих глубинах существуют оптимальные геомеханические условия возникновения самых мощных источников сейсми- ческого излучения. Будут рассмотрены изначальные условия зарождения очагов сильных землетрясений в виде скопления участков фрикционных неустойчивостей между берегами разломов в местах контактного взаимодействия крупных неровностей. Планируется рассмотреть предположения о том, что переход от состояния покоя к динамическому срыву и ускоренному скольжению берегов разрывов в контактной зоне прерывистого скольжения в разломах может быть инициирован как эндогенными факторами, возникающими при стрессметаморфизме, так и дополнительными внешними сейсмодинамическими источниками, например в виде близких сильных землетрясений или постоянных циклических волновых воздействий гравитационной природы. В итоге будет показано, что для создания новых геомеханических моделей сейсмогенерирующих разломов и разработки практических приложений в сфере обеспечения экологической сейсмобезопасности населения необходим мультидисциплинарный подход, способствующий получению принципиально новых знаний. Создание новой методологии предполагает привлечение к тесному сотрудничеству многих специалистов из различных областей наук о Земле - геологии, геофизики, геомеханики, а также физики твердого тела и численного моделирования.

\section{2. СТРОЕНИЕ ПРИПОВЕРХНОСТНЫХ ЗОН СЕЙСМОДИСЛОКАЦИЙ}

\section{1. ОПИСАНИЕ ЗОН СЕЙСМОДИСЛОКАЦИЙ}

В качестве показательного примера ниже представлены сведения, собранные при изучении сейсмодислокаций, возникших в ходе проявления Гоби-Алтайского катастрофического землетрясения в Центральной Монголии 4 декабря 1957 г. с M=8.1 и глубиной гипоцентра 17-23 км [Solonenko, 1960; Florensov, Solonenko, 1963; Kochetkov et al., 1993]. Примечательны проявления динамического вспарывания зоны Долиноозерского разлома, засвидетельствованные сейсмологами и местными жителями в виде ощутимых форшоков еще за несколько месяцев до главного события. При опросах установлено, что за десятки секунд перед главным толчком был слышен низкий гул, вероятно, обусловленный подземными низкочастотными вибрациями звукового диапазона. Примерно за одну минуту до главного события на западном участке генеральной зоны сейсмодислокации, в районе эпицентра, произошел 5-балльный форшоковый толчок, заставивший людей покинуть небольшие строения, которые чуть позднее были полностью разрушены под действием сейсмических сотрясе- 
ний с интенсивностью от 8 до 10-11 баллов по шкале MSK-64. Вслед за тем вдоль северного подножья хребтов Ихэ-Богдо и Бага-Богдо, где проходит зона Долиноозерского разлома, с запада на восток с высокой скоростью распространилась пылевая завеса, сопровождая наблюдаемое перемещение быстрой подвижки по линии вспарывания системы сейсмодислокаций в протяженном сегменте разломной зоны. Губительный главный сейсмический удар ощущался в пределах всей плейстосейстовой области землетрясения, от которого люди теряли сознание на несколько часов, а некоторые животные (чаще всего верблюды) погибали от шока или проваливались в приоткрывшиеся на короткое время трещины. Самые сильные толчки при землетрясении ощущались с перерывами на протяжении трех минут, многочисленные менее сильные толчки происходили еще в течение двух часов. Первые сильные удары сопровождались хорошо видимыми замедленными волновыми деформациями грунтовой поверхности, высота их гребней достигала нескольких метров. Данное описание помогает представить динамику разномасштабного содрогания при вспарывании зоны Долиноозерского разлома и его ответвлений, сформированных еще в среднем палеозое, в период проявления межплитных коллизионных деструктивных процессов в пределах Байкало-Монгольского орогенного пояca.

В целом, генеральная структура многочисленных сейсмодислокаций данного события по свежим следам была закартирована уже в январе 1958 г. участниками Российско-Монгольской экспедиции под руководством В.П. Солоненко [Solonenko, 1960; Florensov, Solonenko, 1963]. Более поздние детальные исследования проводились участниками многочисленных экспедиций из России, Монголии, США, Японии, Франции и других стран. Уместно упомянуть, что к числу важнейших результатов обследования зоны данного землетрясения можно отнести и заложение российскими участниками Советско-Монгольской сейсмогеологической экспедиции, прежде всего Н.А. Флоренсовым и В.П. Солоненко, основы палеосейсмогеологического метода, предназначенного для системного распознавания параметров более древних сильных землетрясений с целью оценки сейсмической опасности. На рис. 1 представлен первый вариант детализированной схемы строения зоны поверхностных сейсмодислокаций Гоби-Алтайского землетрясения.

Согласно сейсмологическим данным, эпицентр землетрясения находился в урочище Бахар, расположенном в западной части зоны Долиноозерского разлома у северного подножья хребта Ихэ-Богдо. От эпицентра магистральная зона сейсмодислокаций лишь на несколько первых десятков километров распространилась к западу, а основное вспарывание по зоне разлома распространилось в юго-восточном направлении на расстояние около 250 км. Морфологическими исследованиями установлен левосторонний взбросо-сдвиговый тип смещений с максимальными амплитудами горизонтальных смещений до 7-8, а вертикальных - до 3-5 м. Наземное и аэровизуальное изучение сейсмодислокаций позволило зафиксировать разнообразие в строении участков зоны их расположения, сохранившихся в виде уступов, рвов, сдвиговых трещин, а также характерных воронок при сдвигах структур pull-apart, иногда наполненных небольшим количеством воды (озерками). Наряду с генеральной зоной сейсмодислокаций у подножья хребтов были выявлены и системы сейсмодислокаций северозападного простирания в пределах массивного поднятия хр. Ихэ-Богдо, в нагорной части которого изза сильнейших сотрясений возникли грандиозные обвалы с амплитудами гравитационного обрушения и сползания горных масс вниз по склону на сотни метров. Наряду с субширотными были зафиксированы сейсмодислокации субмеридионального направления в виде зоны взбросо-сдвига с амплитудой до 4 м по левобережью долины реки Тормхон, что подчеркивает кинематику соизмеримого сейсмогенного перемещения массива хребта Ихэ-Богдо по зоне левостороннего взбросо-сдвига.

При картировании системы сейсмодислокаций фиксировалось характерное сочетание относительно гладких участков зоны с перемычками, где имело место разветвление разрывов, а иногда - их затухание на перемычках между возникшими взбросо-сдвиговыми разрывами. Подобное строение и кинематику сейсмогенного вспарывания генеральной зоны можно рассматривать как последствие объединения относительно мелких косейсмических трещин в более крупные.

Обратимся к другим примерам проявления сейсмогенных деформаций двух катастрофических землетрясений в зоне Северо-Хангайского разлома на севере территории Монголии. Эти события произошли последовательно: 9 июня 1905 г. - Цэцэрлэгское $\left(\mathrm{M}_{\mathrm{w}}=8.0\right)$ и 23 июня - Болнайское $\left(\mathrm{M}_{\mathrm{w}}=8.3-\right.$ 8.5) (рис. 2). Согласно проведенному опросу, среди местных старожилов и их родственников еще сохранились воспоминания о грандиозных разрушительных последствиях этих сейсмических потрясений и косейсмических разрывных нарушениях в зонах разломов, во многом напоминающих последствия Гоби-Алтайского землетрясения.

Возникшие зоны левосторонних взбросо-сдвиговых сейсмодислокаций протяженностью порядка 130 км для Цэцэрлэгского и 276 км для Болнайского сейсмособытия достаточно детально обследовались участниками многих научных экс- 

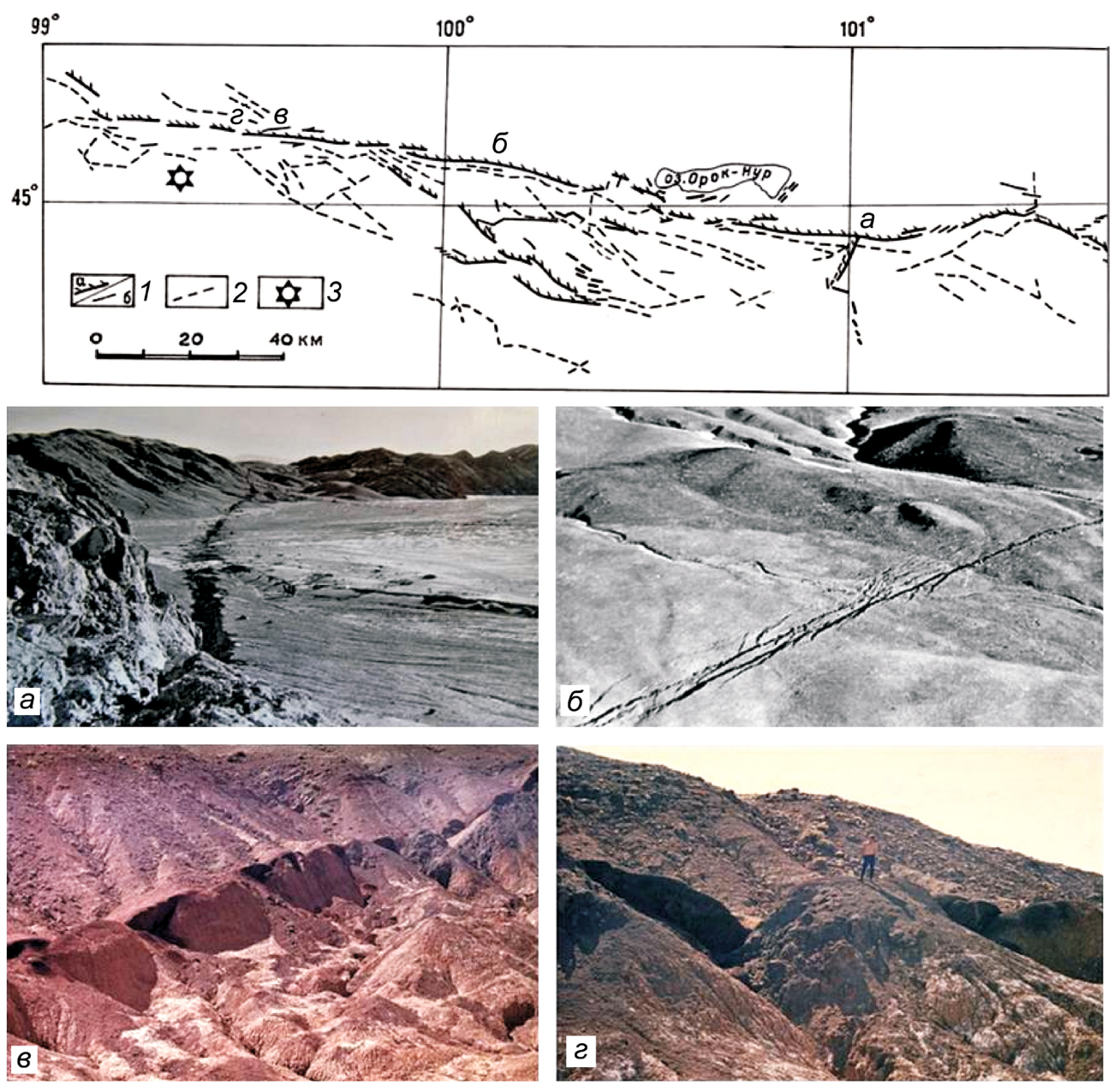

Рис. 1. Вверху представлена упрощенная схема строения зоны взбросо-сдвиговых сейсмодислокаций Гоби-Алтайского землетрясения по [Solonenko, 1960; Florensov, Solonenko, 1963]. 1 - разрывы: а - взбросо-сдвиги, б - трещины растяжения; 2 - другие неизученные разрывы; 3 - эпицентр главного толчка. Буквами на схеме обозначены приведенные ниже фотографии участков магистральной зоны сейсмодислокаций, сделанные В.П. Солоненко и Н.А. Флоренсовым в январе 1958 г.: $a-$ фрагмент генеральной сейсмодислокации, пересекающей долину р. Тормхон (фото Н.А. Флоренсова); б - строение участка генеральной зоны сейсмодислокации в центральной части зоны (снимок В.П. Солоненко с самолета); в, г- косейсмические взбросо-сдвиги в мезозойских глинистых отложениях урочища Хутусудж (фото В.В. Ружича, 1985 г.).

Fig. 1. Top - generalized scheme showing the structure in the zone of reverse-strike-slip seismodislocations of the GobiAltai earthquake (after [Solonenko, 1960; Florensov, Solonenko, 1963]). 1 - ruptures: a - reverse-strike-slip, 6 - tension cracks; 2 - other unexplored ruptures; 3 - main shock epicenter. The letters on the scheme indicate the photos of the major seismodislocation sections (photos taken by V.P. Solonenko and N.A. Florensov in January 1958): $a$ - fragment of the major seismodislocation across the Tormkhon river valley (photo by N.A. Florensov); $\sigma$ - structure of the segment of the major zone of the seismodislocation in the central part of the zone (photo by V.P. Solonenko from the airplane); $8,2-$ coseismic reverse-strike-slip faults in the Mesozoic clay deposits in the Khutusudzh site (photo by V.V. Ruzhich, 1985).

педиций, в первую очередь А.В. Вознесенским [Voznesensky, 1908]. В 2001 г. членами международной монголо-японской экспедиции (при участии В.В. Ружича) была закартирована зона сейсмодислокаций и установлена ее общая протяженность, достигающая 580 (!) км. На основании морфокинематического сходства сдвиговых деформаций при возникновении двух землетрясений и пространственно-временного распределения сейсмодислокаций возможно предположить, что возникновение очага Болнайского катастрофического землетрясения было инициировано деформационным и сейсмовибрационным воздействием со стороны очага Цэцэрлэгского сейсмического события 23 июня 1905 г. Судя по имеющейся информации, подобные сценарии инициации одних подготовленных очагов землетрясений другими не являются редкостью [Nikolaev, Vereshchagina, 1991]. Такие случаи проявления пространственно сближенных и близких по времени сильных землетрясений - со сбли- 


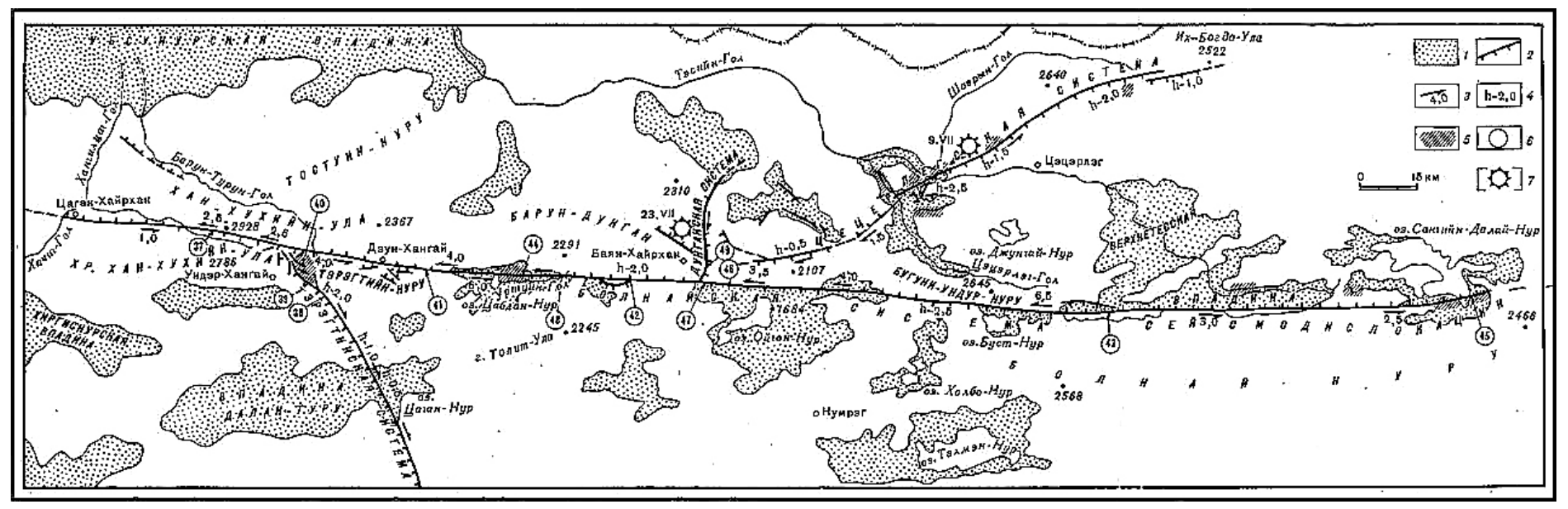

Рис. 2. Строение зон сейсмодислокаций катастрофических землетрясений: Цэцэрлэгского и Болнайского, представленных в работе [Ruzhich, Khil'ko, 1987].

1 - неотектонические впадины; 2 - главные системы сейсмодислокаций (штрихи направлены в сторону опущенных крыльев разрывов); 3 - направление горизонтальных левосторонних и правосторонних смещений; 4 - величина амплитуд максимальных смещений в сейсмодислокациях; 5 - участки рассеянных по площади относительно мелких сейсмогенных разрывов; 6 - нумерация участков детального изучения разрывов; 7 - местоположение эпицентров землетрясений с указанием даты возникновения.

Fig. 2. Structure of the zones of seismodislocations of the Tsetserleg and Bolnay catastrophic earthquakes (after [Ruzhich, Khil'ko, 1987]).

1 - neotectonic depressions; 2 - main systems of seismodislocation (hatching towards the lowered shoulders of the faults); 3 - direction of horizontal left- and right-lateral displacements; 4 - amplitudes of maximum displacements in the seismodislocation; 5 - segments of relatively small seismogenic fractures, which are spatially scattered; 6 - numbers of sites covered by the detailed studies of fractures; 7 locations and dates of earthquake epicenters.

женными эпицентрами, афтершоковыми полями и сейсмодислокациями - известны под названием «дуплетных» сейсмических событий. Механизм их возникновения некоторыми исследователями связывается с замедленной вязкоупругой реакцией блоков горных пород в пределах нижних этажей земной коры или мантии, влиянием которой объясняется наблюдаемая временная задержка между событиями длительностью до нескольких недель [Kocharyan, 2016].

Относительно устройства внутренних сегментов зон рассмотренных сейсмодислокаций можно отметить следующее. В рыхлых грунтах сместители взбросо-сдвиговых сейсмодислокаций проявлялись рассредоточенными цепочками валов и рвов шириной в первые десятки сантиметров или первые метры. В пределах распространения выходов скальных пород сейсмодислокации были представлены в виде незалеченных тонких трещин (иногда с пылеватым налетом сохранившегося продукта истирания горных пород), ширина которых измерялась всего несколькими миллиметрами или первыми сантиметрами.

Повышенное внимание авторов при детальном обследовании сейсмодислокаций уделялось изучению дислокационного метаморфизма горных по- род в зонах разломов, испытавших сейсмогенное обновление, и который был запечатлен в зеркалах скольжения, возникших в древние эпохи сейсмотектонических актов активизации на удалении от поверхности [Ruzhich, 1997]. При прослеживании современных косейсмических разрывов их зоны были представлены в виде пучков косейсмических слабозалеченных разрывов, нередко с новообразованной минерализацией хлорита или кальцита. Подобные признаки начальной стадии минерализации характерны для поверхностных сейсмогенных разрывов с возрастом в несколько сотен - первые тысячи лет. Эти наблюдения также свидетельствуют о приуроченности повторных вскрытий разрывов примерно к одним и тем же сегментам зон тектонических долгоживущих разломов.

\section{2. О ДЛИТЕЛЬНОСТИ АСЕЙСМИЧЕСКИХ ПЕРИОДОВ МЕЖДУ ЗЕМЛЕТРЯСЕНИЯМИ}

Представляющие интерес сведения об оценках скоростей асейсмического крипа в зонах сейсмодислокаций могут быть получены из оценок периодов повторяемости актов косейсмического вспарывания в разломах. Например, для некоторых сегментов зоны Долиноозерского разлома при сей- 
смических циклах землетрясений с $\mathrm{M} \geq 6.0$ оценки были получены при проходке шурфов и канав среди рыхлых осадочных отложений в зоне современной сейсмодислокации Гоби-Алтайского землетрясения, где нередко обнаруживались и более древние сейсмогенные разрывные нарушения. Согласно полученным авторами радиоуглеродным датировкам древесных остатков, погребенных при древних землетрясениях и позднее вскрытых в шурфах, эпизоды последовательного проявления палеоземлетрясений с $\mathrm{M} \approx 6.5-7.5$ имели следующие значения возраста: $230 \pm 50,300 \pm 70,1665 \pm 50,1945 \pm 80$ лет. В таком случае расчетная средняя скорость асейсмического крипа между сильными и катастрофическими землетрясениями при вертикальных смещениях в Долиноозерском разломе может составлять $\approx 1-2$ мм/год.

Прямые измерения скорости тектонического крипа после землетрясения были получены на западном (урочище Хутусудж) и центральном (устье p. Тормхон) участке зоны генеральной сейсмодислокации Гоби-Алтайского землетрясения за период наблюдений 1985-1995 гг. Они осуществлялись как ежегодные топографические измерения на оборудованных полигонах и показали, что сохранилась левосторонняя сдвиговая направленность горизонтальных смещений, а осредненная скорость крипа составляла порядка $1.5 \pm 0.4$ мм/год [Ruzhich, 1996].

В зоне еще более мощного Болнайского катастрофического землетрясения с $\mathrm{M}_{\mathrm{w}}=8.3-8.5$ [Voznesensky, 1908] собраны сведения, которые дают сходные оценки длительности асейсмических периодов. Проходка траншей в некоторых участках сейсмодислокаций показала наличие следов более древних палеосейсмодислокаций, перекрытых новообразованным почвенным слоем высотой порядка 10-14 см. По этим данным, исходя из установленной скорости накопления осадков в данной местности, а также согласно разработанной экспресс-методике, удалось составить представление о длительности асейсмических периодов между сильными сейсмическими событиями. Они также составляли многие сотни или первые тысячи лет. Позднее по результатам радиоуглеродных датировок были получены уточненные значения абсолютного возраста и в первом приближении установлено, что расчетное значение средней скорости крипа в зонах косейсмических разрывов Болнайского разлома составляло порядка 3-7 мм/год, что свидетельствует о более высокой интенсивности взбросо-сдвиговых деформаций в зоне Северо-Хангайского разлома.

Из приведенных примеров описания приповерхностных сейсмодислокаций Цэцэрлэгского, Болнайского и Гоби-Алтайского землетрясений, как и других сейсмических событий подобного уровня, обращает на себя внимание их масштабность. Наличие ответвлений зоны сейсмогенного вспарывания указывает на то, что очаговые косейсмические смещения в верхней части земной коры в большинстве случаев приурочены к активным и длительно существующим разломам. О глубинных механизмах процесса формирования событий подобного масштаба по современным сейсмодислокациям судить невозможно, что заставляет использовать другие методические подходы к их изучению.

\section{3. АНАЛИЗ РЕЗУЛЬТАТОВ БУРЕНИЯ ЗОН СЕЙСМОДИСЛОКАЦИЙ ПОСЛЕ НЕДАВНИХ КАТАСТРОФИЧЕСКИХ ЗЕМЛЕТРЯСЕНИЙ}

Наряду со сведениями о строении приповерхностных зон сейсмодислокаций в глубинных разломах континентов есть возможность рассмотреть весьма ценную новую информацию, собранную по результатам реализации ряда зарубежных проектов быстрого бурения через зоны сейсмогенерирующих разломов. Задачей этих проектов ставилось изучение разнообразных геофизических, геологических и геомеханических процессов, происходящих в зонах сейсмогенерирующих разломов при при подвижках в очагах недавних землетрясений. Участники проектов ставили целью получение ответов на многочисленные вопросы, важные для понимания сейсмотектонических процессов разломообразования на приповерхностном глубинном уровне очагов землетрясений [Brodsky et al., 2009]. Обратимся к примерам.

\section{1. БУРЕНИЕ В ПРЕДЕЛАХ ЗОНЫ РАЗЛОМА САН-АНДРЕАС}

Один из наиболее информативных и дорогостоящих проектов SAFOD (San Andreas Fault Observatory at Depth) был осуществлен в сдвиговой зоне межплитного разлома Сан-Андреас в Центральной Калифорнии на выбранном крипующем сегменте (рис. 3).

Пилотная скважина глубиной 2.2 км была пробурена в 2002 г., а последующее бурение основной скважины, направленной через зону разлома, было осуществлено в три этапа - в 2004, 2005 и 2007 гг. и сопровождалось использованием сейсмологических, геофизических и петрохимических методов исследований. После обсадки ствола при втором этапе бурения на двух участках была зафиксирована прогрессивная деформация трубы из-за смещений по разлому. В этих глубинных интервалах наиболее активной зоны разлома Сан-Андреас были обнаружены следы необычных для таких пара- 
a

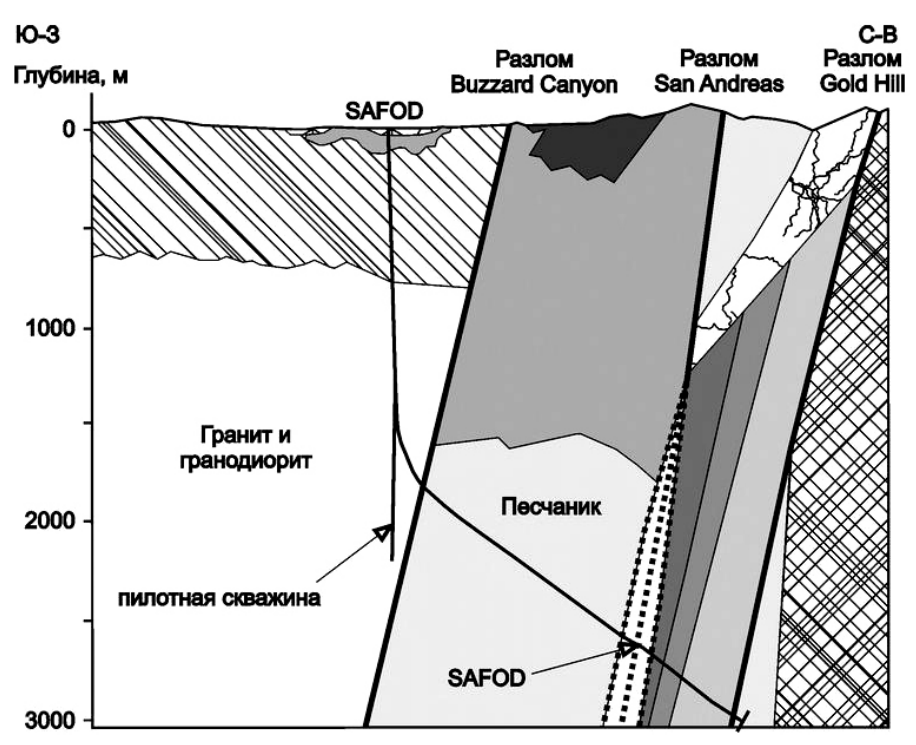

$\sigma$

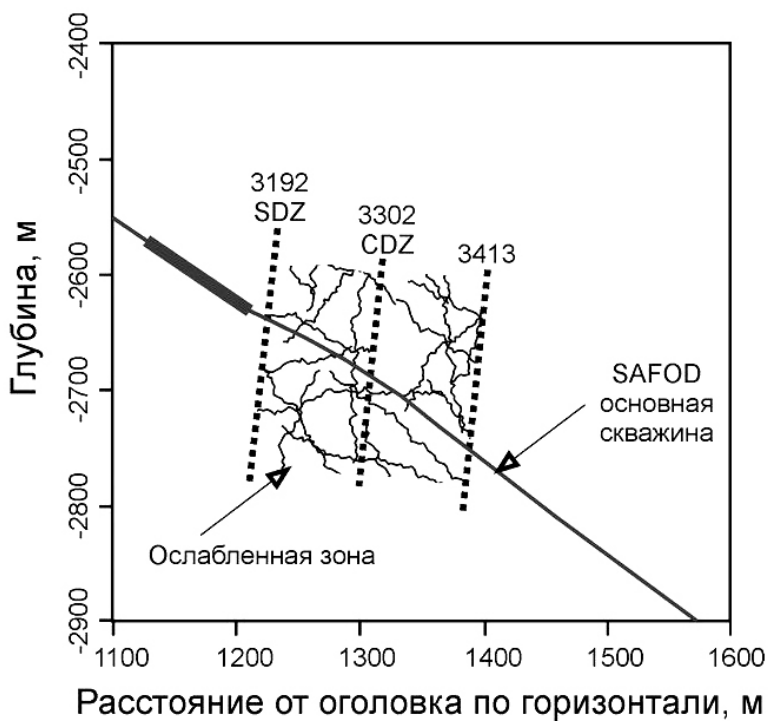

Рис. 3. Упрощенный геологический разрез вдоль траектории скважины SAFOD (a); разрез породного массива с траекторией скважины и основными магистральными зонами, вскрытыми бурением (б) (по данным [Zoback et al., 2010; Jeppson et al., 2010]).

Fig. 3. Generalized geological section along the trajectory of SAFOD wellbore (a). Rock profile (б), which shows the wellbore trajectory and the main fault zones penetrated by drilling (after [Zoback et al., 2010; Jeppson et al., 2010]).

метров минералов - серпентина и талька. Зона разлома на исследованных глубинах располагается в осадочных породах. С юго-запада от разлома скважина SAFOD пересекает мощный слой песчаников. Зоны пониженных, по сравнению с вмещающими породами, скоростей и электрических сопротивлений задокументированы авторами [Zoback et al., 2010] в интервале 3151-3414 м, а по данным [Jeppson et al., 2010] - в интервале от 3190 до 3410 м. Их наличие интерпретируется как результат физико-химических вещественных преобразований горных пород в ходе разломообразования. На глубине 2670 м от поверхности, в скважине SAFOD, был установлен трехкомпонентный геофон, который располагался внутри зоны влияния разлома в 40 м от магистральной зоны. За время работ по проекту сейсмической сетью Северной Калифорнии было с высокой точностью лоцировано 62 слабых землетрясения с гипоцентрами в окрестности зоны влияния разлома на глубинах от 2 до 15 км [Waldhauser, Schaff, 2008]. Часть из них была зарегистрирована прибором, расположенным в скважине SAFOD, что позволило зарегистрировать более 20 событий, источники которых находились внутри зоны разлома [Ellsworth, Malin, 2011]. Построение синтетических сейсмограмм показало, что зона пониженных скоростей в окрестности магистральной части разлома представляет собой канал шириной 30-60 м, проникающий, по крайней мере, на глубину свыше 7 км. В волновых формах от этих событий были выделены каналовые волны, распространяющиеся внутри зоны влияния разломa.

\section{2. БУРЕНИЕ В ПРЕДЕЛАХ ЗОНЫ СЕЙСМОДИСЛОКАЦИЙ ЗЕМЛЕТРЯСЕНИЯ В КОБЕ (ЯПОНИЯ)}

В плейстосейстовой области разрушительного землетрясения 1995 г. с M=7.2 в течение 14 месяцев в гранитном фундаменте было пробурено пять скважин через разлом Nojima Fault. Предварительно было установлено, что полное смещение по разлому за 1.2 млн лет составляет 490-540 м [Murata et al., 2001]. Бурение осуществлялось на двух участках, отстоящих друг от друга примерно на 5 км. Во всех скважинах проводились геофизические исследования, включая акустический каротаж, гаммакаротаж, измерение диаметра скважины, удельного сопротивления, плотности, пористости, температуры, а также обследование извлеченных образцов керна и анализ сделанных из образцов шлифов. Комплексные исследования позволили установить, что магистральный разрыв был вскрыт разными скважинами на глубине 389.5 м. Ствол другой скважины подошел к разлому на глубине примерно 1700 м, но не пересек его [Lin et al., 2007]. Зона динамического влияния разлома определялась как зона умеренно катаклазированных пород, залега- 
ющих между магистральным разрывом и недеформированными породами. Ширина центральной части разлома и зоны влияния составила соответственно 0.3 и 46.5 м в скважине GSJ. В еще одной скважине ширина зоны влияния составила 70-130 м. Отмечается, что разломная зона становится более широкой и сложной с глубиной, разветвляясь на два разлома между скважинами GSJ и NEID. Она представляет собой тонкую малопрочную и низкопроницаемую зону, обрамленную с обеих сторон высокопроницаемой породой, которая подверглась сдвиговым смещениям [Lockner et al., 2009]. Специальные исследования методом электронно-спинового резонанса позволили установить, что имел место фрикционный нагрев в зоне шириной 6 мм. Потемнение глинки трения (gouge) и присутствие образованных окислов железа - признак того, что фрикционный нагрев мог достигать температуры, по меньшей мере, $350-400{ }^{\circ} \mathrm{C}$ при сейсмическом скольжении на глубине 390 м [Fukuchi et al., 2005]. После многих споров специалистами был сделан вывод о том, что зона косейсмического разрыва была найдена на глубине 625.27 м в виде плоскости скольжения толщиной 1 мм. В другой скважине, расположенной на глубине 1140.6 м в зоне скольжения, обнаружен слой тонкоизмельченных минеральных зерен толщиной 10 мм внутри ультракатаклазированного слоя. Д.А. Локнер с соавторами предположили, что скважина пересекла две зоны скольжения на глубинах 1140 и 1312 м [Lockner et al., 2009]. Bce наблюдения в скважинах, пробуренных через Nojima Fault, показывают, что процессы «залечивания» в виде восстановления уровня сдвигового сопротивления в местах плотного контактирования в виде пятен скольжения, вероятно, могут происходить с высокой скоростью, что делает трудным распознавание недавних косейсмических разрывов всего лишь через один год после землетрясения в Кобе (вероятно, из-за явлений механического смыкания стенок разрывов, что фиксировалось в ходе полевых наблюдений в зонах сейсмодислокаций в приповерхностных условиях).

Мощность зоны разлома, структура и минералогия являются следствием двух сильных сейсмических событий, сопровождаемых интенсивными гидротермальными изменениями. Все эти стадии отражаются на строении, минеральном составе и микроструктуре пород разломной зоны. Из них ранний эпизод динамической деформации - левосторонний сдвиг - произошел 56.4 млн лет назад, а более поздний, правосторонний, проявился в четвертичный период. Примечательно, что датировка и оценки физико-химических условий возникновения в трещинах прослоек псевдотахилитов, обнаруженных в магистральной части зоны разлома, показали, что они были образованы на глубине порядка 9 км и подняты на поверхность в течение 40 млн лет [Boullier et al., 2001]. Нетрудно подсчитать, что средняя скорость эксгумации глубинного сегмента разлома в пределах аккреционной призмы к земной поверхности могла составлять порядка 0.225 мм/год.

\section{3. БУРЕНИЕ В ЗОНЕ СЕЙСМОДИСЛОКАЦИЙ ЗЕМЛЕТРЯСЕНИЯ СНI-СНI (ТАЙВАНЬ)}

При землетрясении Chi-Chi (21 сентября 1999 г., $\mathrm{M}=7.6)$ возник сейсмогенный разрыв длиной около 80 км вдоль линии надвига Chelungpu Fault, смещение по которому достигало 10 м (рис. 4). В момент землетрясения северный сегмент разлома испытал большое смещение (8-10 м), высокие скорости скольжения (2-4 м/с), но уровень высокочастотных сейсмических колебаний в ближней зоне был относительно невысок. Напротив, на южном сегменте при меньших амплитудах смещений (3-4 м) и более низких скоростях скольжения $(0.5 \mathrm{~m} / \mathrm{c})$ были зарегистрированы более высокие величины массовых скоростей и ускорений грунта [Ma et al., 2003]. Две вертикальные скважины глубиной 2000.3 м (скважина А) и 1352.6 м (скважина Б) были пробурены в 40 м друг от друга в 2004-2005 гг. Позже в скважине Б был пробурен боковой ствол от 950 м до 1280 м. Скважинами были вскрыты слои песчаников, алевролитов и сланцев, слагающих осадочный покров субдуцирующей плиты.

Три основные разломные зоны были обнаружены в системе разломов Chelungpu Fault. Они были вскрыты скважиной А на глубинах 1111, 1153 и 1221 м, а скважиной Б - на глубинах 1136, 1194 и 1243 м, соответственно. Зона, расположенная на глубине 1111 м в скважине А и 1136 м в скважине B, была идентифицирована как зона разлома землетрясения Chi-Chi. Полная толщина зоны составляет 5.5 м (3.5 м в скважине Б). Другие зоны соответствуют более древним сейсмическим событиям. Особый интерес представляют полученные сведения о последствиях фрикционного нагрева в косейсмических разрывах данного землетрясения. Зона сместителя Chi-Chi была обнаружена в нижней части участка, вскрытого на 1111 м. Она была идентифицирована по целому ряду структурных, минералогических и магнитометрических признаков в шлифах и представляла собой слой толщиной 2 см тонкоперетертого материала (gouge), содержащего обломки матрицы, обломки глинистых агрегатов, смектиты, а также остеклованный материал в малых количествах (0.25 \%). Такие образования являются признаком сейсмического скольжения в богатой глинами gouge-зоне. По разным признакам температура нагрева этой области составляла 


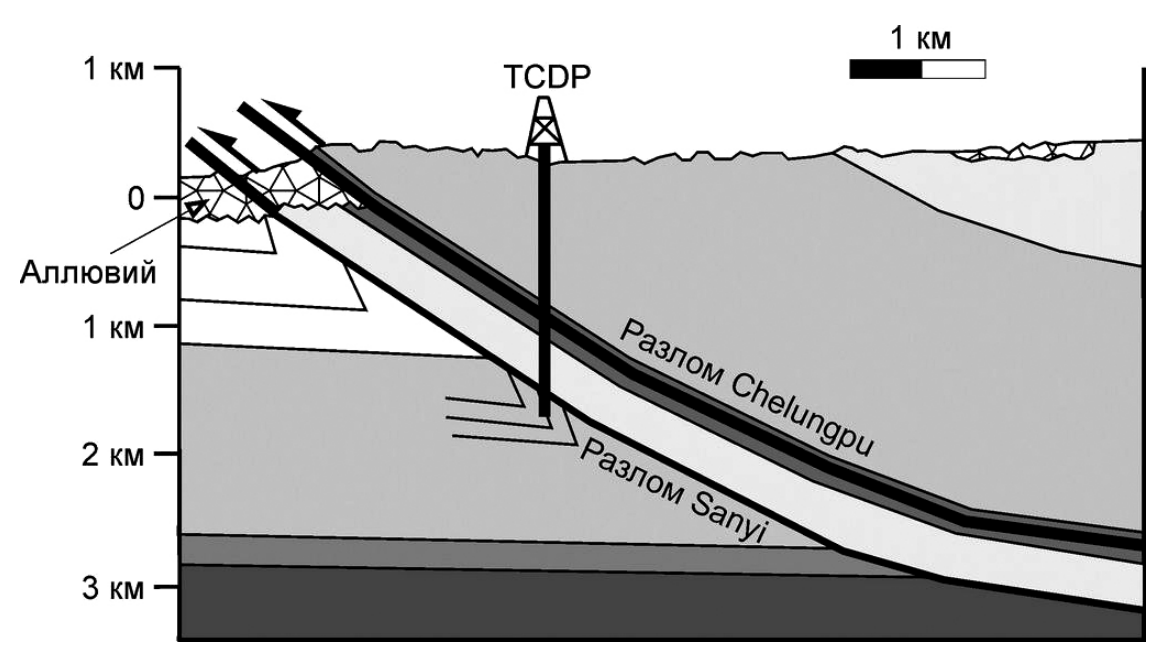

Рис. 4. Схема участка бурения разлома Chelungpu Fault по данным [Boullier et al., 2001; Ma et al., 2003].

| Fig. 4. Schematic map of the drilling site in the Chelungpu Fault zone (after [Boullier et al., 2001; Ma et al., 2003]).

300-400 ${ }^{\circ}$ C. Зона сместителя Chi-Chi в скважине Б заметно тоньше $(0.3 \mathrm{~cm})$ и имеет несколько иной структурный состав. Оценка фрикционного нагрева в этой зоне в скважине Б дает примерно те же значения. В зонах скольжения более древних сейсмических событий (1153 и 1221 м в скважине A; 1314, 1194 и 1243 м в скважине Б) обнаружено заметно большее количество псевдотахилитов. Эти участки сместителя включают также двухсантиметровые диски твердых черных ультракатаклазитов. Оценки показывают, что температура фрикционного разогрева была гетерогенна в отдельных слоях псевдотахилитов и составляла $750-1750{ }^{\circ} \mathrm{C}$.

\section{4. БУРЕНИЕ В ЗОНЕ СЕЙСМОДИСЛОКАЦИЙ ЗЕМЛЕТРЯСЕНИЯ Тохоку-Оки (Япония)}

Сильнейшее современное землетрясение Тохоку-Оки, произошедшее 11 марта 2011 г. (M=9.0), предоставило исследователям огромный массив важной информации о его подготовке и макросейсмических проявлениях. В частности, зафиксировано беспрецедентно большое косейсмическое перемещение с амплитудой около 50 м (!) на мелком участке субдукционной зоны вблизи границы меганадвига у Японского желоба (рис. 5). Проект бурения морского дна в плейстосейстовой области был реализован в апреле-мае 2012 г. с целью разобраться в физических механизмах проявления крупноамплитудных косейсмических смещений в субдукционной зоне. Было пробурено три скважины на 844-850 м ниже поверхности морского дна. Глубина скважин была выбрана на основании предварительно проведенных сейсмических наблюдений, которые выявили зону контактирования поверхности погружающейся океанической плиты с континентальной. В первой скважине проводились разнообразные геофизические исследования, во второй отбирались образцы керна на наиболее важных участках. Третья была предназначена для температурных измерений. Участок бурения располагался приблизительно в 93 км от эпицентра Тохоку-Оки и в 6 км от оси Японского желоба. В этой области косейсмический разрыв землетрясения распространялся с относительно низкой скоростью, характерной для цунамигенных землетрясений. Схема участка приведена на рис. 5 .

Основная зона косейсмического разрыва с признаками видимых литологических изменений принята как верхняя граница погружающейся плиты, расположенная на 820 м ниже дна. Ее центральная часть мощностью около 5 м состоит из слоя коричневой глины с уникальной чешуйчатой структурой. По результатам геоструктурного анализа общая амплитуда смещения вдоль границы плиты в месте бурения составляла порядка 3.2 км, что рассматривается как свидетельство стабильной локализации деформационного процесса на протяжении длительного периода активности разлома. Соприкосновение глины двух цветов демонстрирует бросающийся в глаза контакт в верхней, сильно сдвинутой секции этого участка. Контакт слабоволнистый, с длиной волны сантиметрового масштаба и амплитудой менее 1 мм, срезан без изломов и смят непараллельно контакту. Авторами работы [Chester et al., 2013] сделан вывод о том, что этот контакт есть «запись» косейсмического перемещения, хотя не обязательно, что именно землетрясения Тохоку. Смещение при событии 2011 г. и других последних землетрясениях, вероятно, также происходило по рассмотренной границе раздела плит (820 м ниже дна). Это, в частности, подтверж- 


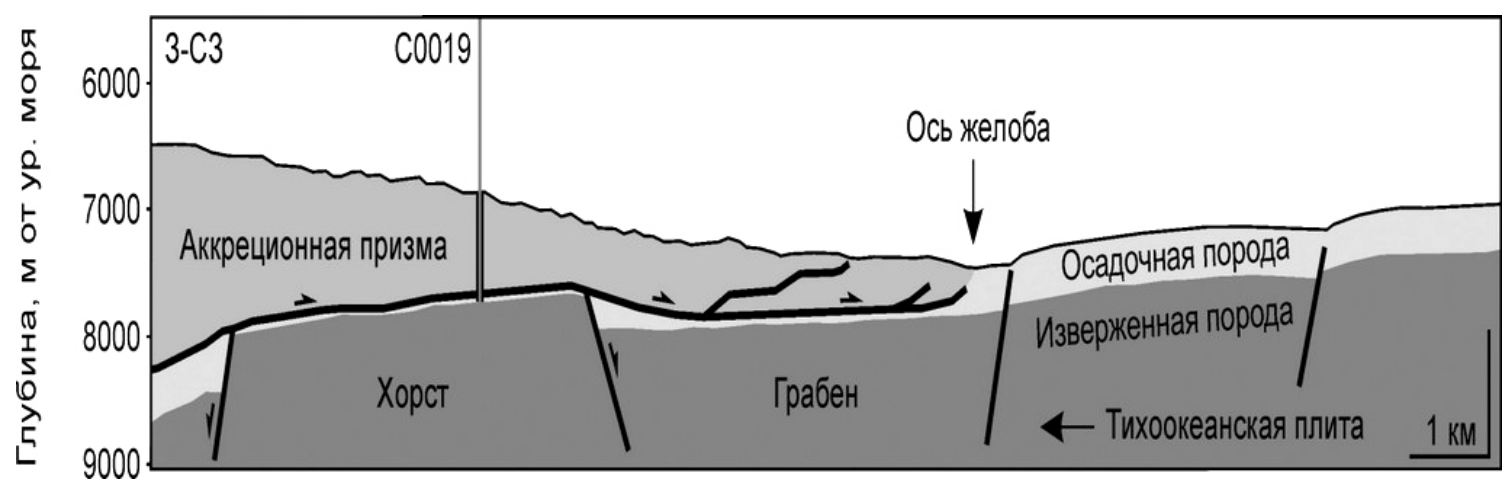

Рис. 5. Схема участка бурения зоны разлома, активизированного при катастрофическом землетрясении ТохокуОки 11.11.2011 г. (по [Chester et al., 2013]).

Fig. 5. Schematic map of the drilling site in the fault zone activated by the catastrophic Tohoku-Oki earthquake of November 11, 2011 (after [Chester et al., 2013]).

дает результат измерения остаточных температурных аномалий. Через 18 месяцев после землетрясения в окрестности этого разлома было зарегистрировано остаточное увеличение температуры в $0.3^{\circ} \mathrm{C}$, приписываемое фрикционному нагреву при скольжении [Fulton et al., 2013]. Однако нельзя исключить, что скольжение имело место и по другим разломам, разрезающим аккреционную призмy.

Глубокое бурение через разломные косейсмические зоны при недавних землетрясениях также проводилось в Китае (Wenchuan Fault Scientific Drilling Program), Европе (Corinth rift, Западная Греция), Южной Африке (NELSAM). В совокупности с результатами традиционных геологических обследований зон разломов на поверхности и в глубоких горных выработках собранные сведения позволяют получить ценные и достаточно объективные представления о структуре различных участков разломных зон, но лишь в приповерхностных горизонтах земной коры.

\section{4. ОБСУЖДЕНИЕ РЕЗУЛЬТАТОВ И ВЫВОДЫ}

Из приведенных примеров описания сейсмодислокаций Болнайского, Цэцэрлэгского и Гоби-Алтайского землетрясений можно сделать следующие выводы о строении и развитии приповерхностных зон косейсмических разрывов. Зарегистрированная протяженность сложнопостроенной системы сейсмодислокаций на земной поверхности, 270-360 км и более, позволяет составить наглядное представление о многоуровневом устройстве и соответствующих масштабных параметрах очаговых сегментов очень сильных землетрясений с $\mathrm{M} \geq 7.0$. Наличие разномасштабных и разно- направленных ответвлений сейсмодислокаций от генеральной зоны сейсмогенного вспарывания указывает на то, что очаговые косейсмические смещения, как правило, периодически возникают по уже существующим системам залеченных и длительно существующих разломов различных направлений [Ruzhich, 1975]. Периоды созревания столь масштабных сейсмотектонических структур составляют сотни - первые тысячи лет, что создает проблемы их прогнозирования из-за ограниченной длительности инструментальных наблюдений. Также следует отметить, что в моменты вспарывания зон сейсмодислокаций происходили многоуровневые разномасштабные переходы в виде объединения мелких трещин в более крупные. Подобный характерный механизм деструкции, наблюдаемый в приповерхностном слое земной коры, проявляется в кристаллических породных массивах при хрупком разрушении. Он согласуется и объективно соответствует известной кинетической концепции прочности при разрушении твердых тел, разработанной Н.С. Журковым [Zhurkov, 1968] и многими его последователями [Sobolev, 1993; Kuksenko et al., 1985; Petrov, 1984; Ruzhich, Khil'ko, 1987, Ruzhich, 1997]. Подобные представления ранее были положены в основу известной модели лавинно-неустойчивого трещинообразования для очагов землетрясений [Sobolev, 1993]. Однако стоит заметить, что подобный режим многоуровневого сейсмогенного вскрытия зон разломов характеризует механизм хрупкого разрушения в упругопластической среде в верхней части земной коры. В отличие от этого механизма, в более глубоких горизонтах земной коры проявляются иные процессы деструкции, для которых характерно вязкоупругое реологическое поведение геологической среды на фоне повышенных давлений и тем- 
ператур в сочетании с участием газоводных флюидов. Для подобных условий более применимы такие модели, как, например, ДД (дилатансионнодиффузионная) и stick-slip [Byerlee, 1978], которые также являются частными [Ruzhich, Khil'ko, 1987]. Например, модель ДД рассматривает более глубинные условия подготовки очагов, при которых учитывается роль флюидного насыщения массивов горных пород при их дилатансионном расширении под нагрузкой на стадии предразрушения [Fyfe et al., 1978]. Модель «stick-slip» является наиболее всеобъемлющей, поскольку основывается на фундаментальном законе трения, т.е. она в общем подходе учитывает влияние фрикционных параметров при прерывистом скольжении берегов разломов, имеющих разнообразную шероховатость. Однако к настоящему времени для понимания эндогенных условий подготовки очагов землетрясений требуются более совершенные модели очагов землетрясений, учитывающие их термобарические и реологические условия на сейсмофокальном уровне земной коры.

Отмеченный недостаток сведений о глубинных процессах в разломах может частично дополняться новой информацией, полученной при оперативном бурении зон сейсмодислокаций до глубины 1-2 км с применением очень сложной технологии, при высокой трудоемкости и стоимости. Такие сведения дают возможность изучать строение внутренних участков зон разломов, заполненных продуктами многократного длительного истирания берегов разрывов и динамического преобразования горных пород в условиях относительно низких температур и давлений. Иногда удается выявить признаки не только современных, но и более древних косейсмических смещений. Но вместе с этим следует отметить их масштабную ограниченность, связанную с размерами керна, поднятого из стволов скважин. Эти точечные способы исследований помогают характеризовать лишь отдельные мелкие геоструктурные детали, нередко попадающие в поле зрения случайным образом при разбуривании. Их значимость относительно огромных по размерам очагов сильных землетрясений протяженностью многие десятки - сотни километров довольно сложно объективно оценить. Остаются непонятными возрастные характеристики возникновения обнаруженного во внутренних сегментах разломов вещества горных пород, претерпевших более существенные физико-химические и механические преобразования в сравнении с поверхностными изменениями.

Чтобы составить представления, в наибольшей степени приближенные к реальному устройству глубинных сегментов очагов сильных землетрясений, далее, во второй части работы (статья II), планируется рассмотреть результаты геологического изучения зон сейсмодислокаций, возникших в средней части земной коры и оказавшихся на земной поверхности после длительной эксгумации глубинных сегментов разломов.

\section{5. БЛАГОДАРНОСТИ}

Авторы выражают признательность анонимным рецензентам за ценные комментарии и замечания, которые помогли улучшить рукопись. Большое спасибо К.Ж. Семинскому, внесшему ряд конструктивных изменений. Представленная статья выполнена при поддержке Российского фонда фундаментальных исследований (проект № 16-05-00694). Проведенные исследования соответствуют государственному заданию плана НИР лаборатории тектонофизики ИЗК СО РАН.

\section{6. ЛИТЕРАTУРA / REFERENCES}

Boullier A.M., Ohtani T., Fujimoto K., Ito H., Dubois M., 2001. Fluid inclusions in pseudotachylytes from the Nojima Fault, Japan. Journal of Geophysical Research: Solid Earth 106 (B10), 21965-21977. https://doi.org/10.1029/2000JB0 00043.

Brodsky E.E., Ma K.F., Mori J., Saffer D.M., 2009. Rapid response fault drilling past, present, and future. Scientific Drilling 8, 66-74. https://doi.org/10.2204/iodp.sd.8.11.2009.

Byerlee J.D., 1978. Friction of rocks. Pure and Applied Geophysics 116 (4-5), 615-626. https://doi.org/10.1007/ BF00876528.

Chester F.M., Rowe C., Ujiie K., Kirkpatrick J., Regalla C., Remitti F., Moore J.C., Toy V., Wolfson-Schwehr M., Bose S., Kameda J., Mori J.J., Brodsky E.E., Eguchi N., Toczko S., Expedition 343 and 343T Scientists, 2013. Structure and composition of the plate-boundary slip zone for the 2011 Tohoku-Oki earthquake. Science 342 (6163), 1208-1211. https://doi.org/10.1126/science.1243719.

Ellsworth W.L., Malin P.E., 2011. Deep rock damage in the San Andreas Fault revealed by P- and S-type fault-zoneguided waves. In: A. Fagereng, V.G. Toy, J.V. Rowland (Eds.), Geology of the Earthquake Source: A volume in honour of Rick Sibson. Geological Society, London, Special Publications, vol. 359, p. 39-53. https://doi.org/10.1144/ SP359.3.

Florensov N.A., Solonenko V.P. (Eds.), 1963. The Gobi-Altai Earthquake. Publishing House of Academy of Sciences of USSR, Moscow, 391 p. (in Russian) [Гоби-Алтайское землетрясение / Ред. Н.А. Флоренсов, В.П. Солоненко. М.: Изд-во АН СССР, 1963. 391 с.]. 
Fukuchi T., Mizoguchi K., Shimamoto T., 2005. Ferrimagnetic resonance signal produced by frictional heating: A new indicator of paleoseismicity. Journal of Geophysical Research: Solid Earth 110 (B12), B12404. https://doi.org/ 10.1029/2004JB003485.

Fulton P.M., Brodsky E.E., Kano Y., Mori J., Chester F., Ishikawa T., Harris R.N., Lin W., Eguchi N., Toczko S., Expedition 343, 343T, and KR13-08 Scientists, 2013. Low coseismic friction on the Tohoku-Oki fault determined from temperature measurements. Science 342 (6163), 1214-1217. https://doi.org/10.1126/science.1243641.

Fyfe W.S., Price N.J., Thompson A.B., 1978. Fluids in the Earth's Crust: Their Significance in Metamorphic, Tectonic, and Chemical Transport Processes. Elsevier, Amsterdam, 383 p. [Русский перевод: Файф У., Прайс Н., Томпсон А. Флюиды в земной коре. М.: Мир, 1981. 436 с.].

Jeppson T.N., Bradbury K.K., Evans J.P., 2010. Geophysical properties within the San Andreas Fault Zone at the San Andreas Fault Observatory at depth and their relationships to rock properties and fault zone structure. Journal of Geophysical Research: Solid Earth 115 (B12), B12423. https://doi.org/10.1029/2010JB007563.

Kocharyan G.G., 2016. Geomechanics of Faults. GEOS, Moscow, 432 p. (in Russian) [Кочарян Г.Г. Геомеханика разломов. М.: ГЕОС, 2016. 432 с.].

Kochetkov V.M., Khil'ko S.D., Zorin Yu.A., Ruzhich V.V., 1993. Seismotectonics and Seismicity of Prikhubsugulie. Nauka Novosibirisk, 280 p. (in Russian] [Кочетков В.М., Хилько С.Д., Зорин Ю.А., Ружич В.В. Сейсмотектоника и сейсмичность Прихубсугулья. Новосибирск: Наука, 1993. 280 с.].

Kuksenko V.S., Manzhikov B.Ts., Mansurov V.A., Mikulin V.A., 1985. Regularities in the development of a microcenter of deformation. Izvestiya AN SSSR, seriya Fizika Zemli (7), 87-93 (in Russian) [Куксенко В.С., Манжиков Б.Ц., Мансуров В.A., Микулин В.A. Закономерности развития микроочага разрушения // Известия АН СССР, серия Физика Земли. 1985. № 7. С. 87-93].

Lin A., Maruyama T., Kobayashi K., 2007. Tectonic implications of damage zone-related fault-fracture networks revealed in drill core through the Nojima Fault, Japan. Tectonophysics 443 (3-4), 161-173. https://doi.org/10.1016/ j.tecto.2007.01.011.

Lockner D.A., Tanaka H., Ito H., Ikeda R., Omura K., Naka H., 2009. Geometry of the Nojima Fault at Nojima-Hirabayashi, Japan - I. A simple damage structure inferred from borehole core permeability. Pure and Applied Geophysics 166 (10-11), 1649-1667. https://doi.org/10.1007/s00024-009-0515-0.

Ma K.F., Brodsky E.E., Mori J., Ji C., Song T.R.A., Kanamori H., 2003. Evidence for fault lubrication during the 1999 Chi-Chi, Taiwan, earthquake (Mw7.6). Geophysical Research Letters 30 (5), 1244. https://doi.org/10.1029/2002GL 015380.

Murata A., Takemura K., Miyata T., Lin A., 2001. Quaternary vertical offset and average slip rate of the Nojima Fault on Awaji Island, Japan. Island Arc 10 (3-4), 360-367. https://doi.org/10.1111/j.1440-1738.2001.00334.x.

Nikolaev A.V., Vereshchagina G.M., 1991. On the initiation of earthquakes by earthquakes. Doklady AN SSSR 318 (2), 320-324 (in Russian) [Николаев А.В., Верещагина Г.М. Об инициировании землетрясений землетрясениями // Доклады АН СССР. 1991. Т. 318. № 2. С. 320-324].

Panza G., Kossobokov V.G., Peresan A., Nekrasova A., 2014. Why are the standard probabilistic methods of estimating seismic hazard and risks too often wrong. In: M. Wyss, J.F. Shroder (Eds.), Earthquake hazard, risk and disasters Elsevier, Amsterdam, p. 309-357. https://doi.org/10.1016/B978-0-12-394848-9.00012-2.

Petrov V.A., 1984. Fundamentals of the kinetic theory of destruction and its prediction. In: Earthquake Forecasting No. 5. Donish, Dushanbe-Moscow, p. 30-44 (in Russian] [Петров В.А. Основы кинетической теории разрушения и ее прогнозирования // Прогноз землетрясений. № 5. Душанбе-Москва: Дониш, 1984. С. 30-44].

Ruzhich V.V., 1975. Influence of ancient fractures on the development of new structures of the Baikal rift. Geologiya $i$ Geofizika (Russian Geology and Geophysics) (1), 130-136 (in Russian) [Ружич В.В. Влияние древних разрывов на развитие новейших структур Байкальского рифта // Геология и геофизика. 1975. № 1. С. 130-136].

Ruzhich V.V., 1996. Tectonic creep in the zones of seismically active faults in Pribaikalie and Mongolia. In: N.A. Logatchev (Ed.), Lithosphere of Central Asia. Nauka, Siberian Publishing Company, Novosibirsk, p. 123-128 (in Russian) [Ружсч B.B. Тектонический крип в зонах сейсмоактивных разломов Прибайкалья и Монголии // Литосфера Центральной Азии / Ред. Н.А. Логачев. Новосибирск: Наука. Сибирская издательская фирма, 1996. C. 123-128].

Ruzhich V.V., 1997. Seismotectonic Destruction of the Earth's Crust in the Baikal Rift Zone. Publishing House of SB RAS Novosibirsk, 144 p. (in Russian) [Ружич B.B. Сейсмотектоническая деструкция в земной коре Байкальской рифтовой зоны. Новосибирск: Изд-во СО РАН, 1997. 144 с.].

Ruzhich V.V., Khil'ko S.D., 1987. Analysis of earthquake sources from seismogeological positions. In: M.A. Sadovsky, G.A. Sobolev (Eds.), Physical bases for prediction of rock destruction by earthquakes. Nauka, Moscow, p. 113-122 (in Russian) [Ружич B.В., Хилько С.Д. Анализ моделей очагов землетрясений с сейсмогеологических позиций // Физические основы прогнозирования разрушения горных пород при землетрясениях / Ред. М.А. Садовский, Г.А. Соболев. М.: Наука, 1987. С. 113-122]

Sobolev G.A., 1993. Fundamentals of Earthquake Prediction. Nauka, Moscow, 310 p. (in Russian) [Соболев Г.А. Основы прогноза землетрясений. М.: Наука, 1993. 310 с.].

Solonenko V.P., 1960. The Gobi-Altai earthquake. Geologiya i Geofizika (Russian Geology and Geophysics) (2), 3-27 (in Russian) [Солоненко В.П. Гоби-Алтайское землетрясение // Геология и геофизика. 1960. № 2. С. 3-27]. 
V.V. Ruzhich, G.G. Kocharyan: On the structure and formation of earthquake sources...

Voznesensky A.V., 1908. Earthquake of June 26 (July 9), 1905 in the Tannu-Ola. Proceedings of the East-Siberian Division of the Imperial Russian Geographical Society 35 (2), 1-10 (in Russian) [Вознесенский А.В. Землетрясение 26 июня (9 июля) 1905 года на Танну-Ола // Известия Восточно-Сибирского отдела Императорского Русского географического общества. 1908. Т. 35. № 2. С. 1-10].

Waldhauser F., Schaff D.P., 2008. Large-scale relocation of two decades of Northern California seismicity using cross-correlation and double-difference methods. Journal of Geophysical Research: Solid Earth 113 (B8), B08311. https://doi.org/10.1029/2007JB005479.

Zhurkov S.N., 1968. Kinetic concept of the strength of solid bodies. Vestnik AN SSSR (Bulletin of the USSR Academy of Sciences) (3), 46-52 (in Russian) [Журков C.Н. Кинетическая концепция прочности твердых тел // Вестник AH CCCP. 1968. № 3. C. 46-52].

Zoback M., Hickman S., Ellsworth W., 2010. Scientific drilling into the San Andreas fault zone. Eos. Transactions American Geophysical Union 91 (22), 197-199. https://doi.org/10.1029/2010E0220001.
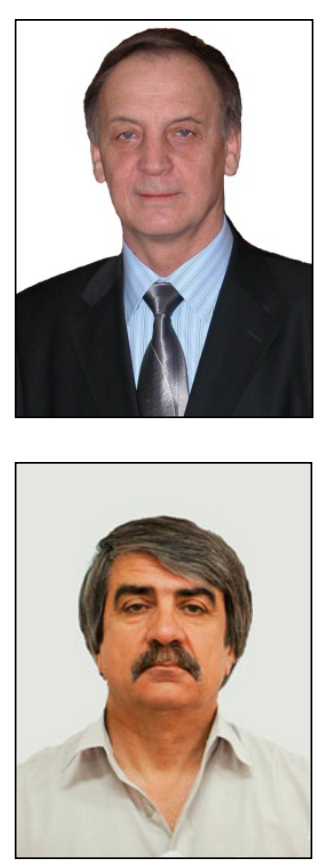

Ружич Валерий Васильевич, докт. геол.-мин. наук, г.н.с. Институт земной коры СО РАН

664033, Иркутск, ул. Лермонтова, 128, Россия

Тел. (3952)422776; \ e-mail: ruzhich@crust.irk.ru

Ruzhich, Valery V., Doctor of Geology and Mineralogy, Chief Researcher Institute of the Earth's Crust, Siberian Branch of RAS

128 Lermontov street, Irkutsk 664033, Russia

Tel. +7(3952)422776; 凶 e-mail: ruzhich@crust.irk.ru

Кочарян Геворг Грантович, докт. физ.-мат. наук, профессор, заведующий лабораторией Институт динамики геосфер РАН

119334, Москва, Ленинский проспект, 38, корпус 1, Россия

Тел.: (495)9397527; e-mail: gevorgk@idg.chph.ras.ru, gevorgkidg@mail.ru

Kocharyan, Gevorg G., Doctor of Physics and Mathematics, Professor, Head of Laboratory Institute of Geosphere Dynamics of RAS

38 Leninsky prospect, Building 1, Moscow 119334, Russia

Tel.: (495)9397527; e-mail: gevorgk@idg.chph.ras.ru, gevorgkidg@mail.ru 